\title{
Investigation of Lead and Iron Removal from Groundwater Using Sapropel and Quartz Sand
}

\author{
Sorphea Heang ${ }^{1}$, Ramunè Albrektienè ${ }^{2 *}$, Dainius Paliulis ${ }^{3}$ \\ ${ }^{1,3}$ Department of Environment Protection and Water Engineering, Faculty of Environmental Engineering, \\ Vilnius Gediminas Technical University, Vilnius, Lithuania \\ ${ }^{2}$ Department of Chemistry and Bioengineering, Faculty of Fundamental Sciences, \\ Vilnius Gediminas Technical University, Vilnius, Lithuania
}

Received 4 February 2020; accepted 31 March 2020

\begin{abstract}
In Prey Nop district of Cambodia, a district in coastal area, it was observed that concentration of iron and lead in groundwater was higher than permissible values. Lead is a highly toxic heavy metal, while iron is an element causing several problems related to the deterioration of taste and aesthetic appearance of water and the capacity reduction of water supply pipelines. Therefore, this article investigates the effectiveness of the technology for removing lead and iron from groundwater using the cheapest materials like sapropel and sand. In this study, different doses of sapropel $(0.1,0.2,0.4,0.5,0.6,0.8,1,2,3,4,5$ and $6 \mathrm{~g} / \mathrm{L})$, different durations of sorption processes $(30,60,90,120$ and 150 $\mathrm{min}$ ) and a laboratory bench for iron filtration filled with quartz sand were used for lead and iron ions removal. Results from the bench tests showed that both iron and lead were removed at efficiencies of 70 and $97 \%$, and their concentrations did not exceed the permissible levels by using the lowest dose of $0.1 \mathrm{~g} / \mathrm{L}$ of sapropel for sorption of lead and filtration through quartz sand filters for iron removal.
\end{abstract}

Keywords: groundwater, lead, iron, sapropel, sand.

\section{Introduction}

The Kingdom of Cambodia is located in the Southeast Asia region. Two types of water are available in Cambodia, in which surface water stands for the abundant water resources. Besides, groundwater in Cambodia is of good quality, but in some areas it contains higher level of lead, arsenic, manganese, fluoride, iron, affecting public health of people in those areas (Peng \& Pin, 2002). In Prey Nop district, a district in coastal area, it was observed that concentration of iron and lead in groundwater was higher than permissible values.

Lead is one of the most dangerous heavy metal for ecosystems since it possesses strong toxic properties. Lead is a highly poisonous metal having effect on almost every organ in the body. The nervous system is the mainly affected target in lead toxicity (Akers et al., 2015; Wani et al., 2015). Lead tends to accumulate in the body and may cause adverse effects: central nervous system damage; gastrointestinal lead is absorbed by 5-10\% in adults and 50\% in children; $80-100 \%$ of inhaled lead enters the bloodstream; it accumulates in hair, nails and bones (Schamphelaere et al., 2014; Liu et al., 2014).

Lead is one of the most dangerous components of wastewater. Natural lead pollution occurrences from volcanic explosions and forest fire. Non-natural sources are human, from the industry and transportation (Zhang et al., 2015). Road transport, together with the exhaust, emits up to $75 \%$ of the lead contained in petrol. Renovation of old steel structures may result in the formation of large quantities of lead dust. The metallurgical industry, lead processing and fuel plants also contribute to environmental pollution by lead compounds. Other sources are from manufacturing batteries, coal burning, type casting, and older houses and buildings (Woolf et al., 2007; Zhang et al., 2009). When burning lead-containing waste - capsules, tubes, synthetic materials, anti-corrosion paint, the pollutants are released into the air and then deposit on the soil and get into water bodies. Lead contamination of groundwater could be associated to the seepage of irrigation water, corrosion of buried metallic structure (largely of iron), and leachate from the industrial dust pile (Sadiq \& Alam, 1997). Sanitary landfills remain the most cost effective option for disposal of solid waste (Islam \& Singhal, 2002) especially for many municipalities in developing countries. However, groundwater pollution from the leachate generated within the landfill and migrating through the liner material into the underlying aquifers is big problem (Fatta et al., 1999). Major exposure pathways of pollution also include intake of lead by consuming lead-

*Corresponding author. E-mail: ramune.albrektiene@vgtu.lt 
contaminated water and food. Food can become contaminated with lead from the soil and water in the growing environment, or from the materials used in processing or cooking, or the containers used in storage. Lead concentrations in drinking water in China, Poland, Japan, Singapore, India, USA and Cambodia have been found to exceed the permitted level (in the EU defined as $10 \mu \mathrm{g} / \mathrm{L}$ by Directive 98/83/EC (The Council of the European Union, 1998)) (Chen et al., 2015; Li et al., 2015; Lu et al., 2015; Jurgens et al., 2019).

Lead concentration in water can be reduced by nanofiltration, membrane filtration (Gholami et al., 2014). Adsorption is often used for lead removal (Bhatia et al., 2017). Adsorption using nanosorbents has a higher efficiency in removing chemical elements (Ngulube et al., 2017). However, majority of these techniques cause several undesirable effects namely chemical requirements, complexity, low efficiency, and usually large amounts of sludge produced causing other environmental problems. Compared with other treatment methods, adsorption is generally the most effective method due to its merits of efficiency, free-sludge (Gupta et al., 2011). For this reason, numerous studies have been investigating the adsorption by using low-cost sorbents. Various sorbents are used to remove heavy metals: biomass, activated carbon, red clay, zeolites, magnetite, aluminium, carbon nanotubes, chitosan, copper, iron, manganese and zinc oxides, aluminium sorbents, bentonite (Bhatia et al., 2017; Badawi et al., 2017; Golbad et al., 2017; Kocaoba \& Arisoy, 2018; Zou et al., 2019). Oak bark, mahogany bark, lignin, rice shells, clay, modified peat, bamboo pulp, sawdust, active sewage sludge, modified wool, palm tree waste fibres, saffron flower waste etc. can be also used as sorbents (Mishra \& Patel, 2009; Alhogbi et al., 2019; Khohsang \& Ghaffarinejad, 2018). It has also been found that lead is effectively removed by sapropel. Sapropel is a silty sediment or sediment formed on the bottom of fresh, slack water bodies. The organic material consists of lignin-humus mix, carbohydrates and bitumens (Stankevica et al., 2014). Depending on sapropel composition, it is categorized into organic (50-90\% of organic matter by dry weight), calcareous (30-60\% of calcium carbonate), siliceous (25-45\% of silicon dioxide) and mixed varieties (Bakšienè, 2006). Sapropel has the property of sorbing heavy metals as much as up to $97.4 \%$ from solution, depending on contact time and concentration of heavy metals in the solution (Birgèlaite et al., 2016). An enhancement of efficiency in removing lead from aqueous solution or groundwater is a crucial point that most of the scientific researchers have been developing. Keeping this in mind, environmental and physicochemical conditions for conducting an experiment have been carefully considered in order to reach an optimal efficiency. Maximum removal capacity of $\mathrm{Pb}$ ions was affected by its initial concentration, adsorbent dose, contact time, $\mathrm{pH}$, metal speciation, temperature, and presence of $\mathrm{NO}_{3}{ }^{-}$and $\mathrm{Cl}^{-}\left(\mathrm{Mouflih}^{-}\right.$ et al., 2006; Liu \& Zhang, 2009; Mishra \& Patel, 2009; Fan et al., 2017).

Investigations of health professionals have shown that higher levels of iron in water do not adversely affect human health (Lieu et al., 2001), but cause a number of other problems in the water supply for consumers: the interaction of soluble divalent iron compounds with oxygen in the air produces low-soluble brownish trivalent iron hydroxides, and the water becomes cloudy, its taste and aesthetic appearance deteriorate. These clouds settle on various plumbing fixtures and need to be removed periodically. Another problem is that aerated iron water flowing through the pipelines causes the accumulation of iron bacteria, that immobilize trivalent iron hydroxide, on these pipelines. As these substances accumulate, the diameter of the pipelines and their throughput are reduced. Bacterial activity products can give water an unpleasant odor. As the water pressure fluctuates in the system, more iron sediments appear from the tap (Vreeburg \& Boxall, 2007; Marjani et al., 2009). For these reasons, the World Health Organization (WHO) recommends that the concentration of iron in drinking water supplied to consumers should not exceed $300 \mu \mathrm{g} / \mathrm{L}$. Under Council Directive 98/83/EC, the concentration of total iron in drinking water must not exceed $200 \mu \mathrm{g} / \mathrm{L}$. Iron is removed from groundwater by the conversion (oxidation) of soluble divalent iron into insoluble trivalent iron compounds which are then filtered. The rate of iron oxidation depends on water temperature, $\mathrm{pH}$, alkalinity, hydrogen sulfide content and other parameters. The higher the $\mathrm{pH}$ value of the water, the faster the divalent iron is oxidized to the trivalent. It is also necessary to consider the grain size of the filters, their composition, uniformity, porosity, chemical and mechanical resistance. Various filters are used for iron removal. Catalytic filters such as Nevtraco natural dolomite filler are used as well as granular filtration fillers based on manganese dioxide based Pyrolox, Greensand, Birm. The simplest, cheapest and most widely used is quartz sand (Veressinina et al., 2000; Lee et al., 2009).

The purpose of this article is to investigate the effectiveness of the technology for simultaneously removing lead and iron from groundwater using the cheapest materials such as sapropel and sand.

\section{Materials and methods}

According to one investigation of the groundwater quality in Prey Nop district of Cambodia, a district in coastal area, it was observed that concentration of iron and lead in groundwater was higher than permissible values (Table 1).

The first type of test water was deionized water contaminated with lead(II) ions with the concentration of lead(II) ions of $0.07 \mathrm{mg} / \mathrm{L}$. This concentration of lead in water has been chosen by taking into account the chemical composition of the water taken from the Prey Nop area of Cambodia.

Stock solutions of lead(II) (1000 \pm 2 ppm, Buck Scientific, USA) were used for GFAAS calibration. Standard solutions with the required lead(II) ion concentrations were prepared by appropriate dilution with deionized water. The $\mathrm{pH}$ of every solution was maintained at a desired value by adding $0.01 \mathrm{M} \mathrm{NaOH}$ or $0.01 \mathrm{M} \mathrm{HNO}_{3}$. 
Test water was prepared from dilution of stock solution of $\mathrm{Pb}$ (II) in one-litre measuring flasks with deionised water. 6 flasks of $1 \mathrm{~L}$ with $0.07 \mathrm{mg} / \mathrm{L} \mathrm{Pb}$ (II) of test water were used for the tests.

The temperature has the impact on the adsorption process. As the temperature increases, the adsorption process can be activated due to the increase of surface area of the sorbent. The optimum temperature for the adsorption process is between $30^{\circ} \mathrm{C}$ and $70^{\circ} \mathrm{C}$ (Badawi et al., 2017). Experimental adsorption tests were performed at room temperature at $20 \pm 2{ }^{\circ} \mathrm{C}$.

Table 1. Quality data of groundwater in Prey Nop district, Cambodia

\begin{tabular}{|c|c|}
\hline Parameters & Amount \\
\hline $\mathrm{pH}$ & 5.25 \\
\hline Electrical conductivity, $\mu \mathrm{S} / \mathrm{cm}$ & 32.2 \\
\hline Turbidity, NTU & 6.95 \\
\hline Dissolved oxygen, $\mathrm{mg} / \mathrm{L}$ & 2.52 \\
\hline Total dissolved solid, $\mathrm{mg} / \mathrm{L}$ & 1660 \\
\hline Ammonia, $\mathrm{mg} / \mathrm{L}$ & 0.05 \\
\hline Nitrite, $\mathrm{mg} / \mathrm{L}$ & 0.001 \\
\hline Iron, $\mathrm{mg} / \mathrm{L}$ & 0.958 \\
\hline Lead, $\mathrm{mg} / \mathrm{L}$ & 0.0702 \\
\hline
\end{tabular}

The raw sapropel was extracted from 2-3 m depth of the Apslavas lake located in Stabulankliai village, Leliūnai local municipality, Utena district, Lithuania. The sapropel sample was taken to analyse its composition and to conduct the further experiments. The chemical (elemental) composition of sapropel was investigated by X-ray fluorescence spectrometer with wave variance Axios MAx (manufacturer PANalytical, Netherlands). An X-ray source of $4 \mathrm{~kW}$ power with Rh (rhodium) anode. The chemical composition was calculated using the betalon methodology and Omnian software (PANalytical, Netherlands). The mineral composition was investigated by powder X-ray diffraction (Powder X-ray diffraction). Used X-ray diffractometer SmartLab (manufacturer Rigaku, Japan). Analysis was made using the EVA software (Bruker AXS) and X-ray database PDF-2. The carbon content was determined by the carbon and sulphur analyser CS-2000 (Manufacturer ELTRA, Germany). The composition of sapropel is shown in Table 2.

Table 2. Chemical composition data of the sapropel

\begin{tabular}{|c|c|c|c|}
\hline Element & {$[\%] \mathrm{w} / \mathrm{w}$} & Compound & {$[\%] \mathrm{w} / \mathrm{w}$} \\
\hline $\mathrm{C}$ & 6.616 & $\mathrm{CO}_{2}$ & 0.105 \\
\hline $\mathrm{O}$ & 56.325 & $\mathrm{Na}_{2} \mathrm{O}$ & 0.489 \\
\hline $\mathrm{Na}$ & 0.363 & $\mathrm{MgO}$ & 0.462 \\
\hline $\mathrm{Mg}$ & 0.279 & $\mathrm{Al}_{2} \mathrm{O}_{3}$ & 4.916 \\
\hline $\mathrm{Al}$ & 2.602 & $\mathrm{SiO}_{2}$ & 65.000 \\
\hline $\mathrm{Si}$ & 30.383 & $\mathrm{P}_{2} \mathrm{O}_{5}$ & 0.091 \\
\hline $\mathrm{P}$ & 0.040 & $\mathrm{SO}_{3}$ & 0.413 \\
\hline $\mathrm{S}$ & 0.165 & $\mathrm{Cl}$ & 0.011 \\
\hline $\mathrm{Cl}$ & 0.011 & $\mathrm{~K}_{2} \mathrm{O}$ & 1.712 \\
\hline $\mathrm{K}$ & 1.422 & $\mathrm{CaO}_{2}$ & 1.246 \\
\hline $\mathrm{Ca}$ & 0.890 & $\mathrm{TiO}_{2}$ & 0.245 \\
\hline $\mathrm{Ti}$ & 0.147 & $\mathrm{Cr}_{2} \mathrm{O}_{3}$ & 0.040 \\
\hline $\mathrm{Cr}$ & 0.027 & $\mathrm{MnO}$ & 0.013 \\
\hline $\mathrm{Mn}$ & 0.010 & $\mathrm{Fe}_{2} \mathrm{O}_{3}$ & 0.940 \\
\hline $\mathrm{Fe}$ & 0.657 & $\mathrm{NiO}$ & 0.003 \\
\hline $\mathrm{Ni}$ & 0.003 & $\mathrm{CuO}$ & 0.001 \\
\hline $\mathrm{Cu}$ & 0.001 & & 0.003 \\
\hline $\mathrm{Zn}$ & 0.003 & & \\
\hline
\end{tabular}


End of Table 2

\begin{tabular}{|c|c|c|c|}
\hline Element & {$[\%] \mathrm{w} / \mathrm{w}$} & Compound & {$[\%] \mathrm{w} / \mathrm{w}$} \\
\hline $\mathrm{Rb}$ & 0.005 & $\mathrm{Rb}_{2} \mathrm{O}$ & 0.006 \\
\hline $\mathrm{Sr}$ & 0.005 & $\mathrm{SrO}$ & 0.006 \\
\hline $\mathrm{Y}$ & 0.002 & $\mathrm{Y}_{2} \mathrm{O}_{3}$ & 0.002 \\
\hline $\mathrm{Zr}$ & 0.024 & $\mathrm{ZrO}_{2}$ & 0.032 \\
\hline $\mathrm{Ba}$ & 0.013 & $\mathrm{BaO}$ & 0.015 \\
\hline $\mathrm{Pb}$ & 0.007 & $\mathrm{PbO}$ & 0.008 \\
\hline
\end{tabular}

The sorbent for the adsorption studies were washed twice with deionized water, dried for 3 hours in a drying oven at $110 \pm 2{ }^{\circ} \mathrm{C}$. The dried substance was crushed in a porcelain mortar to a homogeneous mass and spread through a $0.2 \mathrm{~mm}$ sieve.

Dry sapropel in the doses of 1, 2, 3, 4, 5 and $6 \mathrm{~g}$ was weighed with analytical scales. The prepared sorbent was added to the prepared $1 \mathrm{~L}$ six containers with test water contaminated with lead(II) ions. The test water was mixed with sorbents in a magnetic stirrer at $200 \mathrm{rpm}$.

5 water samples were taken in the quantities of $25 \mathrm{ml}$ after different contact times: 30, 60, 90, 120 and $150 \mathrm{~min}$ (Ö. Gerçel \& H. Gerçel, 2007). After adsorption, the solution was filtered through a membrane filter (47 mm diameter, pore size $0.45 \mu \mathrm{m})$. After filtration the concentrations of lead(II) ions were determined by using atomic absorption spectrometry (AAS; model Buck Scientific 210 VGP, USA) operated with graphite furnace, a slit of $0.7 \mathrm{~mm}$ at $283.2 \mathrm{~nm}$ wavelength. A chemical modifier $\left(\mathrm{NH}_{4} \mathrm{H}_{2} \mathrm{PO}_{4}\right)$ was used for possible alleviation of matrix interferences, which are normally severe during graphite furnace analysis for lead.

Due to the comparatively low concentration of lead after removal with high doses of sapropel - a more detailed study with lower doses of sapropel is required. The second test was designed to determine the conditions under which sapropel adsorbs lead(II) ions best at low doses of sorbent $-0.1,0.2,0.4,0.5,0.6$ and $0.8 \mathrm{~g} / \mathrm{L}$, and the concentration of lead (II) ions in water was measured after 30, 60, 90, 120 and 150 minutes (Ö. Gerçel \& H. Gerçel, 2007).

A laboratory batch experimental setup of iron removal, as shown in Figure 1, was developed to measure the filtration of iron with filter media. To construct filter column, $1.20 \mathrm{~m}$ in length and diameter of $0.055 \mathrm{~m}$ of plastic column was prepared and connected with faucet to regulate and stabilize the flow rate of filtration. Inside of the column, gravel ranging from $2-2.5 \mathrm{~mm}$ in size was put into the column at $10.5 \mathrm{~cm}$ from bottom of column as supporting layer and the sand was then gradually added into to the column to achieve a $80 \mathrm{~cm}$ filter depth from upper gravel layer.
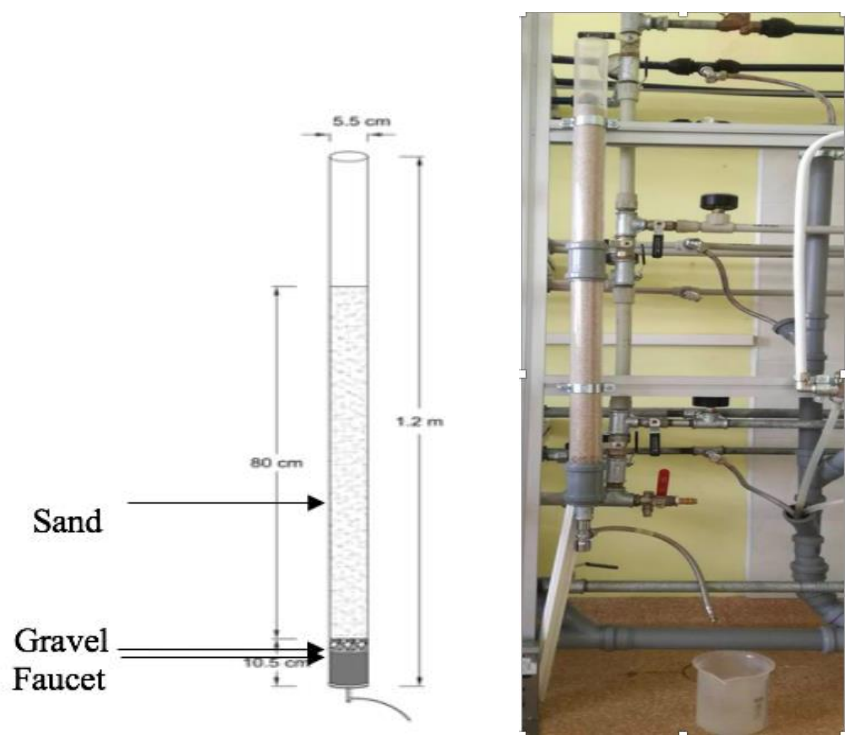

Figure 1. Experimental setup of iron removal

To establish the efficiency of combined steps including adsorption with sapropel, aeration during stirring and sand filtration in removing both lead and iron ions from water the second type of synthetic water was used in the experiments (solution of lead(II) and iron(II) with concentrations of $0.07 \mathrm{mg} / \mathrm{L}$ and $0.9 \mathrm{mg} / \mathrm{L}$, respectively). The $1 \mathrm{~L}$ of synthetic water was mixed with the lowest dose of sapropel, $0.1 \mathrm{mg} / \mathrm{L}$. The solutions were then stirred using magnetic drives connected with straight blade impeller at $200 \mathrm{rpm}$ under room temperature for 30,60 and 90 min. Filtration 
column filtrated $1 \mathrm{~L}$ of stirred solutions with flow velocity of $8.5 \mathrm{~m}^{3} / \mathrm{m}^{2} / \mathrm{h}$. Lead and iron concentrations in filtrate were measured using Atomic Absorption Spectrophotometer and photometer, respectively.

Water quality assessment tests after mixing were performed based on the following standards:

Determination of lead concentration in water was carried out according to ISO 15586 Water quality - Determination of trace elements using atomic absorption spectrometry with graphite furnace (International Organization for Standardization [ISO], 2003).

Determination of total iron concentration in water was carried out according to ISO 6332 Water quality - Determination of iron - Spectrometric method using 1,10-phenanthroline (ISO, 1988).

According to Council directive 98/83/EC of 3 November 1998 on the quality of water intended for human consumption the result is acceptable, when Trueness and Precision of method is less than $10 \%$.

Trueness is a measure of systematic error, i.e. the difference between the mean value of the large number (10 measurements) of repeated measurements and the true value. Stock solutions of lead(II) is $0.01 \mathrm{mg} / \mathrm{L}$ and iron $200 \mu \mathrm{g} / \mathrm{L}$ according to Council directive 98/83/EC of 3 November 1998 on the quality of water intended for human consumption parametric value of lead is $10 \mu \mathrm{g} / \mathrm{L}$ and iron $200 \mu \mathrm{g} / \mathrm{L}$. Precision is a measure of random error and is usually expressed as the standard deviation (within and between batches) of the spread of results from the mean. Acceptable precision is twice the relative standard deviation (Table 3).

Table 3. Trueness and precision of method

\begin{tabular}{|l|c|c|c|c|}
\hline & Trueness of lead & Precision of lead & Trueness of iron & Precision of iron \\
\hline Average value, $\mu \mathrm{g} / \mathrm{L}$ & 9.7 & 10.12 & 196.5 & 202.2 \\
\hline Assigned value, $\mu \mathrm{g} / \mathrm{L}$ & 10.0 & 10.0 & 200 & 200 \\
\hline Standard deviation, $\mu \mathrm{g} / \mathrm{L}$ & 0.24 & 0.39 & 3.16 & 3.03 \\
\hline Relative standard deviation, $\%$ & 2.4 & 3.9 & 1.61 & 1.82 \\
\hline Acceptable trueness, \% & 4.8 & 7.8 & 3.22 & 3.64 \\
\hline
\end{tabular}

The obtained result of the analysis is the arithmetical average of concentrations of three samples, when distribution does not exceed $5 \%$, if higher tested were repeated. $95 \%$ confidence interval was calculated.

\section{Results and discussion}

In the first stage of the study, the task was to determine how the presence of sapropel in aqueous solution affected the quantity of lead. The sapropel dose is a main variable for the quantitative removal of lead ions from model groundwater. Optimization of the dose of the sapropel used was performed with a model lead solution of concentration about $0.07 \mathrm{mg} / \mathrm{L}$ which is similar to those in a natural groundwater in Cambodia. The process was conducted for various contact times in the range of $30,60,90,120$ and $150 \mathrm{~min}$ at ambient temperature $20 \pm 2{ }^{\circ} \mathrm{C}$ using various quantities of sapropel, 1, 2, 3, 4, 5 and $6 \mathrm{~g} / \mathrm{L}$. The experimental data obtained are shown in Figure 2.

Having completed the analysis of the lead ion sorption using different doses of sapropel and different sorption times, Figure 2 shows that using all doses of sapropel from 1 to $6 \mathrm{~g} / \mathrm{L}$ and the sorption process times from the shortest one of $30 \mathrm{~min}$ to the longest time of $150 \mathrm{~min}$, the lead concentration is effectively reduced to $100 \%$ and no longer exceeds the allowable limits. The most efficient removal of lead ions by sorption at different times occurs at a sapropel dose of $6 \mathrm{~g} / \mathrm{L}$. At different doses of sapropel, lead ion concentration is most effectively reduced by the longest sorption process of $150 \mathrm{~min}$. This study suggests that sapropel doses of less than $1 \mathrm{~g} / \mathrm{L}$ can be used to remove lead ions.

Figure 3 shows the removal of lead ions using different sapropel doses $(0.1,0.2,0.4,0.5,0.6$ and $0.8 \mathrm{~g} / \mathrm{L})$ and at different sorption times (30, 60, 90, 120 and $150 \mathrm{~min}$ ).

Having completed the analysis of the lead ion sorption using different doses of sapropel and different sorption times, Figure 3 shows that using all doses of sapropel from 0.1 to $0.8 \mathrm{~g} / \mathrm{L}$ and the sorption process times from the shortest one of $30 \mathrm{~min}$ to the longest time of $150 \mathrm{~min}$, the lead concentration is effectively reduced and no longer exceeds the allowable limits. Lead removal efficiency ranges from $91 \%$ to $99 \%$. Lead ion sorption of 30 min shows the tendency that with the increase of the sorbent dose the efficiency of lead ion removal decreases. At longer sorption times, this tendency disappears. For shorter sorption times (30 and $60 \mathrm{~min}$ ), the most effective dose of sapropel is $0.1 \mathrm{~g} / \mathrm{L}$. With increased sorption time $(90,120$ and $150 \mathrm{~min})$, the most effective dose of sapropel is $0.8 \mathrm{~g} / \mathrm{L}$. Lead ions are removed very efficiently (91 to $99 \%$ ) at all sorption times. Since all doses of sapropel have very high lead removal efficiency and lead is removed to the allowable limits, the smallest sapropel dose of $0.1 \mathrm{~g} / \mathrm{L}$ will be used for further economic calculations. 

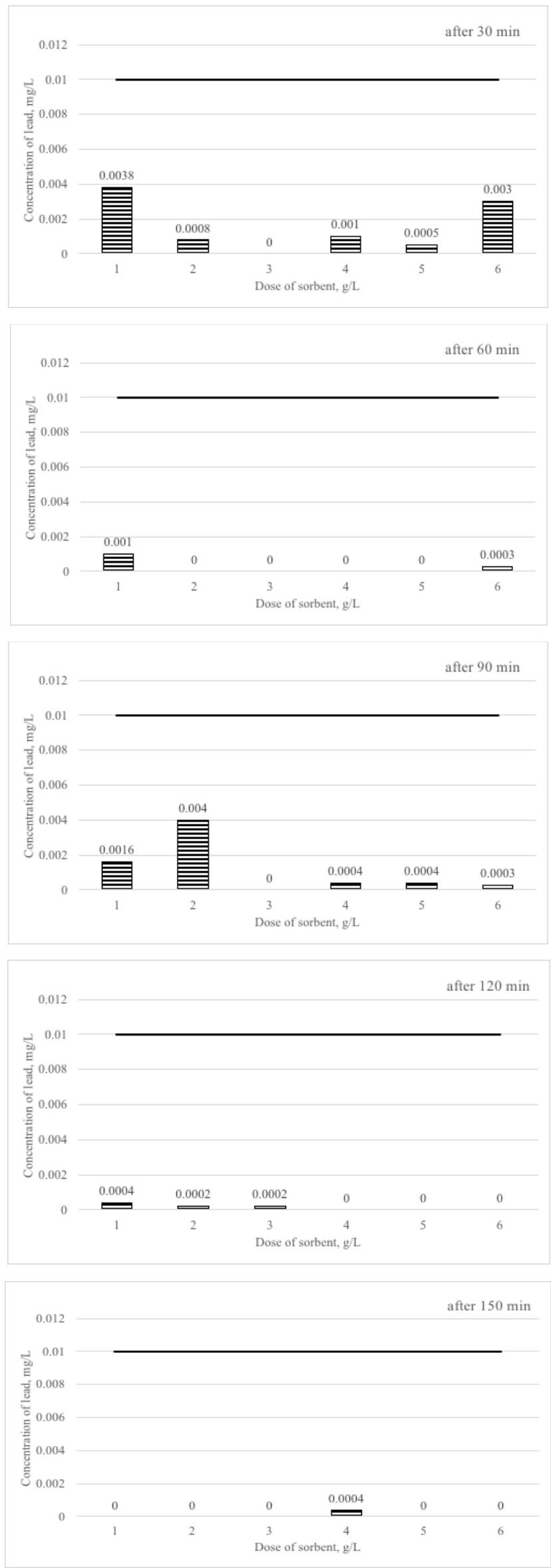

Figure 2. Effect of adsorbent dosage and contact time on adsorption of $\mathrm{Pb}$ ions. Initial lead concentration $0.07 \mathrm{mg} / \mathrm{L}$ 


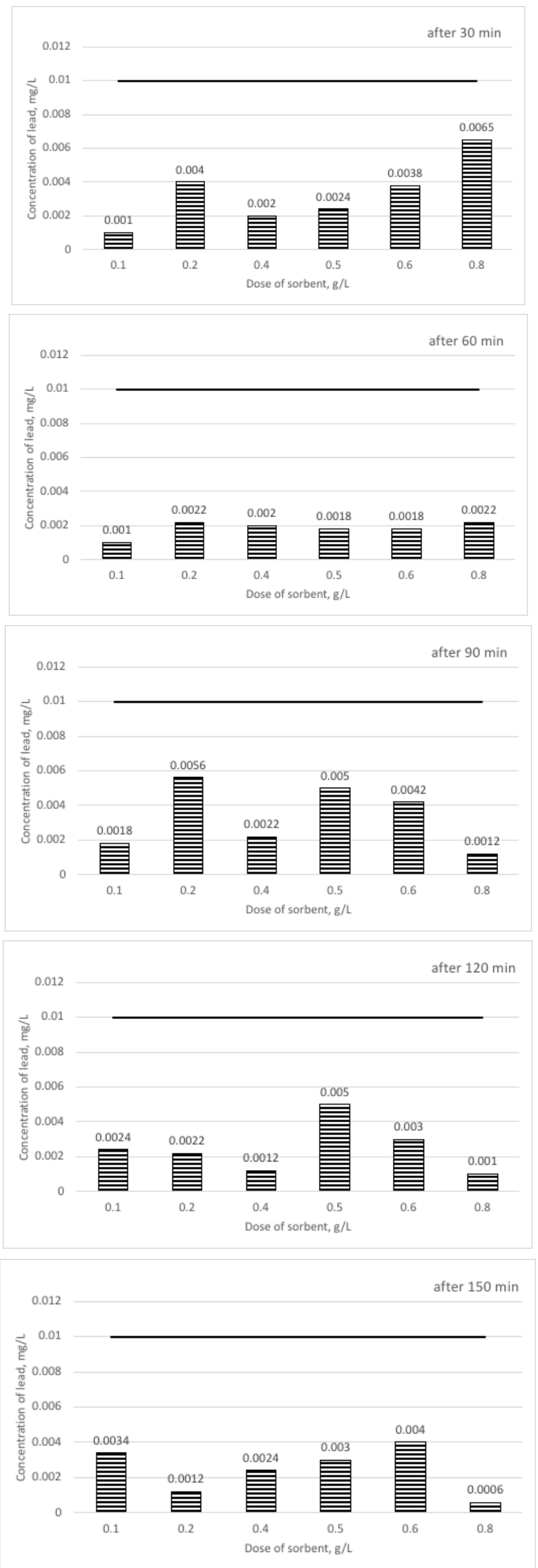

Figure 3. Effect of adsorbent dosage and contact time on adsorption of $\mathrm{Pb}$ ions. Initial lead concentration $0.07 \mathrm{mg} / \mathrm{L}$ 
Figure 4 shows the simultaneous removal of iron and lead ions in a laboratory bench using three different times of sorption process $(30,60$ and $90 \mathrm{~min}$ ) at a sapropel dose of $0.1 \mathrm{~g} / \mathrm{L}$ and filtration of water through a sand filter at $8.5 \mathrm{~m}^{3} / \mathrm{m}^{2} / \mathrm{h}$ speed.

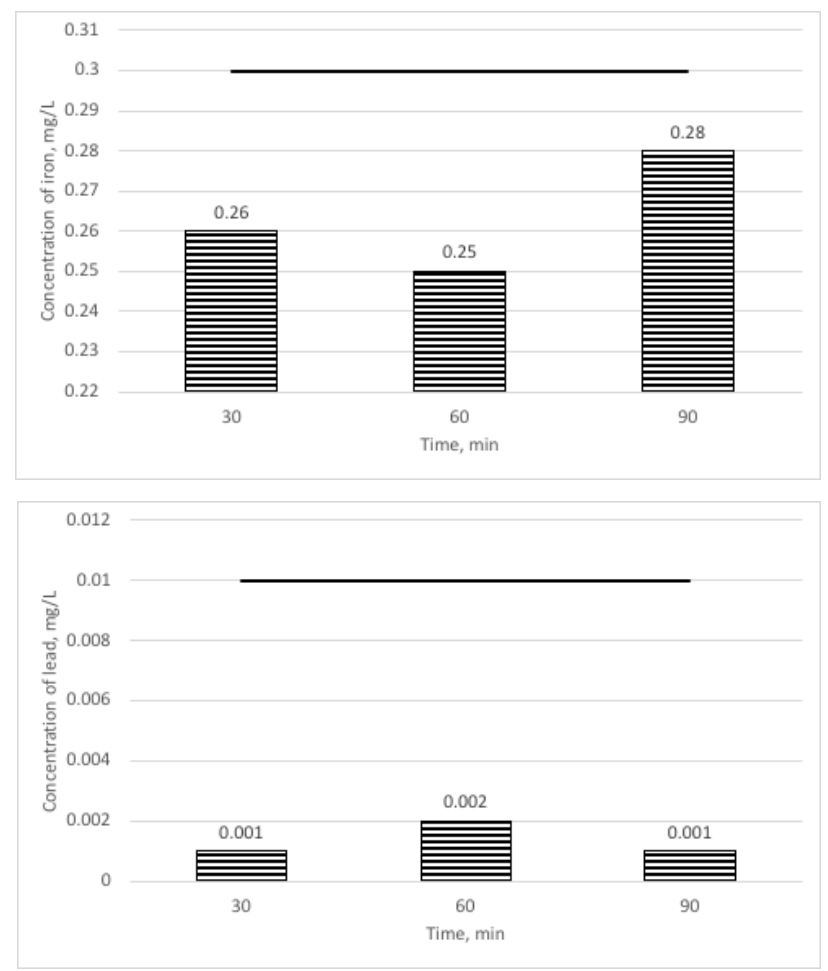

Figure 4. Iron and lead removal efficiency in experimental setup at different lead sorption times. Initial iron and lead concentrations are 0.9 and $0.07 \mathrm{mg} / \mathrm{L}$

Iron and lead ion removal bench tests, using different sorption times, showed that by using a minimum sapropel dose of $0.1 \mathrm{~g} / \mathrm{L}$ for lead sorption and filtration through quartz sand filters for iron removal, both iron and lead were removed efficiently (70 and 97\%) and their concentrations did not exceed the permitted limits. At different sorption times, the removal efficiency of iron and lead ions is practically unchanged, so we can use the shortest sorption time of 30 minutes in this technology.

\section{Conclusions}

1. The lead ion sorption study using different doses of sapropel and different sorption times showed that using all sapropel doses from 1 to $6 \mathrm{~g} / \mathrm{L}$ and the sorption process from the shortest time $30 \mathrm{~min}$ to the longest time $150 \mathrm{~min}$, the concentration of lead ions is very effectively reduced to $100 \%$ and no longer exceeds the allowable limits.

2. The lead ion sorption study using different doses of sapropel and different sorption times showed that using all sapropel doses from 0.1 to $0.8 \mathrm{~g} / \mathrm{L}$ and the sorption process from the shortest time $30 \mathrm{~min}$ to the longest time $150 \mathrm{~min}$, the concentration of lead ions is very effectively reduced and no longer exceeds the allowable limits. Lead removal efficiency ranges from $91 \%$ to $99 \%$.

3. For shorter sorption times (30 and $60 \mathrm{~min}$ ), the most effective dose of sapropel is $0.1 \mathrm{~g} / \mathrm{L}$. With increasing sorption time (90, 120 and $150 \mathrm{~min})$, the most effective dose of sapropel is $0.8 \mathrm{~g} / \mathrm{L}$.

4. Iron and lead ion removal bench tests, using different sorption times, showed that by using a minimum sapropel dose of $0.1 \mathrm{~g} / \mathrm{L}$ for lead sorption and filtration through quartz sand filters to remove iron, both iron and lead were removed efficiently (70 and 97\%) and their concentrations did not exceed the permitted limits.

\section{References}

Akers, D. B., MacCarthy, M. F., Cunningham, J. A., Annis, J., \& Mihelcic, J. R. (2015). Lead (Pb) Contamination of self-supply groundwater systems in coastal Madagascar and predictions of blood lead levels in exposed children. Environmental Science \& Technology, 49(5), 2685-2693. https://doi.org/10.1021/es504517r

Alhogbi, B. G., Salam, M. A., \& Ibrahim, O. (2019). Environmental remediation of toxic lead ions from aqueous solution using palm tree waste fibers biosorbent. Desalination and Water Treatment, 145, 179-188. https://doi.org/10.5004/dwt.2019.23507 
Badawi, M. A., Negm, N. A., Abou Kana, M. T., \& Abdel Moneem, M. M. (2017). Adsorption of aluminum and lead from wastewater by chitosan-tannic acid modified biopolymers: Isotherms, kinetics, thermodynamics and process mechanism. International Journal of Biological Macromolecules, 99, 465-476. https://doi.org/10.1016/j.ijbiomac.2017.03.003

Bakšienè, E. (2006, September 20-23). The effects of lakes sapropels on the changes in sandy loam cambisol properties and on the crop productivity. Paper presented at International Conference on: Information Systems in Sustainable Agriculture, Agroenvironment and Food Technology, Volos, Greece.

Bhatia, M., Satish Babu, R., Sonawane, S. H., Gogate, P. R., Girdhar, A., Reddy, E. R., \& Pola, M. (2017). Application of nanoadsorbents for removal of lead from water. International Journal of Environmental Science and Technology, 14, 1135-1154. https://doi.org/10.1007/s13762-016-1198-6

Birgèlaitè, R., Valskys, V., \& Ignatavičius, G. (2016). Use of sapropel for removal of heavy metals from solution. Science - Future of Lithuania, 8(4), 388-396. https://doi.org/10.3846/mla.2016.946

Chen, M., Lee, J. M., Nurhati, I. S., Switzer, A. D., \& Boyle, E. A. (2015). Isotopic record of lead in Singapore Straits during the last 50 years: Spatial and temporal variations. Marine Chemistry, 168, 49-59. https://doi.org/10.1016/j.marchem.2014.10.007

Fan, C., Du, B., Zhang, Y., Gao, Y., \& Chang, M. (2017). Adsorption of lead on organo-mineral complexesisolated from loess in northwestern China. Journal of Geochemical Exploration, 176, 50-56. https://doi.org/10.1016/j.gexplo.2016.02.012

Fatta, D., Papadopoulos, A., \& Loizidou, M. (1999). A study on the landfill leachate and its impact on 25 the groundwater quality of the greater area. Environmental Geochemistry and Health, 21, 175-190. https://doi.org/10.1023/A:1006613530137

Gholami, A., Moghadassi, A. R., Hosseini, S. M., Shabani, S., \& Gholami, F. (2014). Preparation and characterization of polyvinyl chloride based nanocomposite nanofiltration-membrane modified by iron oxide nanoparticles for lead removal from water. Journal of Industrial and Engineering Chemistry, 20(4), 1517-1522. https://doi.org/10.1016/j.jiec.2013.07.041

Golbad, S., Khoshnoud, P., \& Abu-Zahra, N. (2017). Hydrothermal synthesis of hydroxy sodalite from fly ash for the removal of lead ions from water. International Journal of Environmental Science and Technology, 1, 135-142. https://doi.org/10.1007/s13762-016-1133-x

Gerçel, Ö., \& Gerçel, H. (2007). Adsorption of lead (II) ions from aqueous solutions by activated carbon prepared from biomass plant material of Euphorbia rigida. Chemical Engineering Journal, 132(1), 289-297. https://doi.org/10.1016/j.cej.2007.01.010

Gupta, V. K., Agarwal, S., \& Saleh, T. A. (2011). Synthesis and characterization of alumina-coated carbon nanotubes and their application for lead removal. Journal of Hazardous Materials, 185(1), 17-23. https://doi.org/10.1016/j.jhazmat.2010.08.053

International Organization for Standardization. (2003). Water quality - Determination of trace elements using atomic absorption spectrometry with graphite furnace (ISO 15586:2003).

International Organization for Standardization. (1988). Water quality - Determination of iron - Spectrometric method using 1,10-phenanthroline (ISO 6332:1988).

Islam, J., \& Singhal, N. (2002). A one-dimensional multi-component landfill leachate transport model. Environmental Modelling \& Software, 17, 531-543. https://doi.org/10.1016/S1364-8152(02)00009-9

Jurgens, B. C., Parkhurst, D. L., \& Belitz, K. (2019). Assessing the lead solubility potential of untreated groundwater of the United States. Environmental Science and Technology, 53(6), 3095-3103. https://doi.org/10.1021/acs.est.8b04475

Khohsang, H., \& Ghaffarinejad, A. (2018). Rapid removal of lead (II) ions from aqueous solutions by saffron flower waste as a green biosorbent. Journal of Environmental Chemical Engineering, 5, 6021-6027. https://doi.org/10.1016/j.jece.2018.09.020

Kocaoba, S., \& Arisoy, M. (2018). Biosorption of cadmium(II) and lead(II) from aqueous solutions using Pleurotus ostreatus immobilized on bentonite. Separation Science and Technology, 11, 1703-1710. https://doi.org/10.1080/01496395.2018.1442477

Lee, S. M., Tiwari, D., Choi, K. M., Yang, J. K., Chang, Y. Y., \& Lee, H. D. (2009). Removal of Mn(II) from Aqueous Solutions Using Manganese-Coated Sand Samples. Journal of Chemical \& Engineering Data, 54, 1823-1828. https://doi.org/10.1021/je800854s

Li, P., Lin, C., Cheng, H., Duan, X., \& Lei, K. (2015). Contamination and health risks of soil heavy metals around a lead/zinc smelter in southwestern China. Ecotoxicology and Environmental Safety, 113, 391-399. https://doi.org/10.1016/j.ecoenv.2014.12.025

Lieu, P. T., Heiskala, M., Peterson, P. A., \& Yang, Y. (2001). The roles of iron in health and disease. Molecular Aspects of Medicine, 22, 1-87. https://doi.org/10.1016/S0098-2997(00)00006-6

Liu, G., Yu, Y., Hou, J., Xue, W., Liu, X., Liu, Y., Wang, W., Alsaedi, A., Hayat, T., \& Liu, Z. (2014). An ecological risk assessment of heavy metal pollution of the agricultural ecosystem near a lead-acid battery factory. Ecological Indicators, 47, $210-218$. https://doi.org/10.1016/j.ecolind.2014.04.040

Liu, Z., \& Zhang, F. S. (2009). Removal of lead from water using biochars prepared from hydrothermal liquefaction of biomass. Journal of Hazardous Materials, 167, 933-939. https://doi.org/10.1016/j.jhazmat.2009.01.085

Lu, L., Cheng, H., Liu, X., Xie, J., Li, Q., \& Zhou, T. (2015). Assessment of regional human health risks from lead contamination in Yunnan Province, Southwestern China. PLoS One, 10(3), e0119562. https://doi.org/10.1371/journal.pone.0119562

Marjani, A., Nazari, A., \& Seyyed, M. (2009). Alteration of iron level in drinking water by aeration in Gonbad Kavoos (North East of Iran). American Journal of Biochemistry and Biotechnology, 5(2), 94-97. https://doi.org/10.3844/ajbbsp.2009.94.97

Mishra, P. C., \& Patel, R. K. (2009). Removal of lead and zinc ions from water by low cost adsorbents. Journal of Hazardous Materials, 168, 319-325. https://doi.org/10.1016/j.jhazmat.2009.02.026

Mouflih, M., Aklil, A., Jahroud, N., Gourai, M., \& Sebti, S. (2006). Removal of lead from aqueous solutions by natural phosphate. Hydrometallurgy, 81(3), 219-225. https://doi.org/10.1016/j.hydromet.2005.12.011

Ngulube, T., Gumbo, J. R., Masindi, V., \& Maity, A. (2017). An update on synthetic dyes adsorption onto clay based minerals: A state-ofart review. Journal of Environmental Management, 191(15), 35-57. https://doi.org/10.1016/j.jenvman.2016.12.031 
Peng, P., \& Pin, N. (2002, December 10-12). Groundwater contamination in Cambodia. Paper presented at ESCAP-IWMI Seminar on Environmental and Public Health Risks Due to Contamination of Soils, Crops, Surface and Groundwater from Urban, Industrial and Natural Sources in South East Asia, Hanoi, Vietnam.

Sadiq, M., \& Alam, I. (1997). Lead contamination of groundwater in an industrial complex. Water, Air, and Soil Pollution, 98, 167-177. https://doi.org/10.1007/BF02128655

Schamphelaere, K. A. C., Nys, C., \& Janssen, C. R. (2014). Toxicity of lead (Pb) to freshwater green algae: Development and validation of a bioavailability model and inter-species sensitivity comparison. Aquatic Toxicology, 155, 348-359. https://doi.org/10.1016/j.aquatox.2014.07.008

Stankevica, K., Klavins, M., Rutina, L., \& Cerina, A. (2012). Lake sapropel: a valuable resource and indicator of lake development. Advances in Environment, Computational Chemistry and Bioscience, 2012, 247-252.

The Council of the European Union. (1998). Council Directive 98/83/EC of 3 November 1998 on the quality of water intended for human consumption. Official Journal L 330, 05/12/1998 P. 0032-0054. https://eur-lex.europa.eu/legal-content/EN/TXT/?uri=CELEX\%3A31998L0083

Veressinina, Y., Trapido, M., Ahelik, V., \& Munter, R. (2000). Catalycit filtration for the improvement drinking water quality. Proceedings of the Estonian Academy of Sciences. Chemistry, 49(3), 168-179.

Vreeburg, J. H. G., \& Boxall, J. B. (2007). Discoloration in potable water distribution systems: A review. Water Research, 41, 519-529. https://doi.org/10.1016/j.watres.2006.09.028

Wani, A. L., Ara, A., \& Usmani, J. A. (2015). Lead toxicity: A review. Interdisciplinary Toxicology, 8(2), 55-64. https://doi.org/10.1515/intox-2015-0009

Woolf, A. D., Goldman, R., \& Bellinger, D. C. (2007). Update on the clinical management of childhood lead poisoning. Pediatric Clinics of North America, 54(2), 271-294. https://doi.org/10.1016/j.pcl.2007.01.008

Zhang, R., Wilson, V. L., Hou, A., \& Meng, G. (2015). Source of lead pollution, its influence on public health and the countermeasures. International Journal of Health Animal Science \& Food Safety, 2(1), 18-31.

Zhang, Y., Wang, X., Chen, H., Yang, X., Chen, J., \& Allen, J. O. (2009). Source apportionment of lead-containing aerosol particles in Shanghai using single particle mass spectrometry. Chemosphere, 74, 501-507. https://doi.org/10.1016/j.chemosphere.2008.10.004

Zou, Ch., Jiang, W., Sun, X., \& Guan, Y. (2019). Removal of Pb(II) from aqueous solutions by adsorption on magnetic bentonite. Environmental Science and Pollution Research, 26, 1315-1322. https://doi.org/10.1007/s11356-018-3652-0 